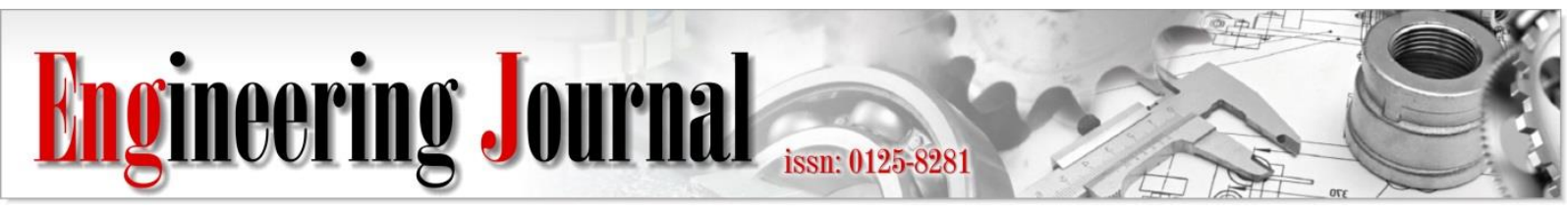

Article

\title{
Analysis of Tropospheric Nitrogen Dioxide Using Satellite and Ground Based Data over Northern Thailand
}

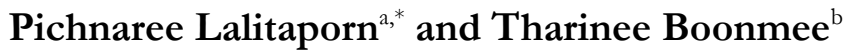 \\ Department of Environmental Engineering, Faculty of Engineering, Kasetsart University, Bangkok 10900, \\ Thailand \\ E-mail: afengprla@ku.ac.th (Corresponding author), btharinee_4@hotmail.com
}

\begin{abstract}
Tropospheric $\mathrm{NO}_{2}$ columns over northern Thailand were analyzed using monthly satellite products of the SCIMACHY, OMI, GOME-2A, and GOME-2B sensors for the 14-year period 2003-2016. The comparative results of the four pairs of different satellite datasets within overlapped years showed that they were well correlated with correlation coefficients ( $\mathrm{r}$ ) of $0.85-0.90$ when the analysis was considered only during the dry period. Ground measurements of $\mathrm{NO}_{2}$ concentrations were also obtained for comparative analysis with the satellite $\mathrm{NO}_{2}$ columns. The results revealed relatively good agreement between these two parameters for a seasonal pattern. High levels of $\mathrm{NO}_{2}$ were detected during January-April. Overall, the r-values of the satellite and ground datasets during the dry period were in the range $0.54-0.81$. Moreover, most satellite and ground datasets recorded greater levels of $\mathrm{NO}_{2}$ in the afternoon than in the morning corresponding with the number of fire hotspots. Satellite and ground measurements showed slightly increasing trends of $\mathrm{NO}_{2}$ levels during dry months for 2010-2016 with values of $7.23 \%$ and $0.48 \%$, respectively, over the 6year period. The results in this study suggest that integrating satellite and ground data would provide valuable information for air quality managers to better understand the spatiotemporal distribution of $\mathrm{NO}_{2}$ which is essential for setting air quality policy and mitigation plan in Thailand.
\end{abstract}

Keywords: $\mathrm{NO}_{2}$, GOME-2, OMI, SCIAMACHY, MODIS, fire hotspots.

ENGINEERING JOURNAL Volume 23 Issue 6

Received 25 August 2018

Accepted 5 August 2019

Published 30 November 2019

Online at http://www.engj.org/

DOI:10.4186/ej.2019.23.6.19 


\section{Introduction}

Nitrogen dioxide $\left(\mathrm{NO}_{2}\right)$ is one of the important trace gases playing significant roles in atmospheric chemistry and climate change. In terms of greenhouse gas, $\mathrm{NO}_{2}$ contributes significantly to the local radiative forcing of climate over polluted regions (such as large urban areas or areas with extensive biomass burning) by perturbing methane $\left(\mathrm{CH}_{4}\right)$ and ozone $\left(\mathrm{O}_{3}\right)$ concentrations [1]. In the troposphere, when $\mathrm{NO}_{2}$ is present in sunlight, $\mathrm{O}_{3}$ is formed as a result of the photolysis of $\mathrm{NO}_{2}$ [2] $\mathrm{NO}_{2}$ can also generate secondary inorganic aerosol and secondary organic aerosol through a series of chemical reactions and physical processes [3]. In addition, the formation of nitric acid $\left(\mathrm{HNO}_{3}\right.$ the main component of acid rain) due to the chemical reaction of $\mathrm{NO}_{2}$ and hydroxyl radicals $(\mathrm{OH})$ is the dominant sink of $\mathrm{NO}_{2}$ in the troposphere during daytime and summertime [4]. The presence of $\mathrm{NO}_{2}$ in the troposphere also causes adverse impacts on human health, crops and ecosystems [5-6]. The main sources of $\mathrm{NO}_{2}$ include anthropogenic activities such as fossil-fuel combustion, biomass burning and fertilizer application, as well as natural sources such as wildfires, lightning and microbiological processes in soil [7-9]. The chemical lifetime of tropospheric $\mathrm{NO}_{2}$ is relatively short varying from hours to days in the atmospheric boundary layer depending on the season [10].

Advances in satellite instruments have allowed access to information on the global distribution of atmospheric $\mathrm{NO}_{2}$ over the past decades. Many researchers [11-15] have applied satellite-retrieved data of tropospheric $\mathrm{NO}_{2}$ columns for air quality study since the Global Ozone Monitoring Experiment (GOME) onboard the ERS-2 platform was launched in 1995. The next generation of satellite $\mathrm{NO}_{2}$ instruments was the SCanning Imaging Absorption spectroMeter for Atmospheric CHartographY (SCIAMACHY) onboard Envisat in 2002, followed by the Ozone Monitoring Instrument (OMI) onboard Aura in 2004, and GOME2 onboard MetOp-A (GOME-2A) and MetOp-B (GOME-2B) in 2006 and 2012, respectively. Boersma et al. [16] validated urban $\mathrm{NO}_{2}$ concentrations retrieved from OMI and SCIAMACHY using ground in situ measurements in Israeli cities in 2006. Both satellite and ground observations showed higher winter $\mathrm{NO}_{2}$ levels than for summer. In addition, SCIAMACHY recorded higher $\mathrm{NO}_{2}$ levels than OMI in summer, but lower in winter. Hilboll et al. [17] investigated long-term trends (1996-2011) of tropospheric $\mathrm{NO}_{2}$ over megacities using multisatellite observations. They found significantly decreasing trends in the developed world such as Western Europe, the United States, and Japan. However, strongly increasing trends of 5-10\% per year were found over China, India, and the Middle East. Similar results were reported in Schneider et al. [18] using SCIAMACHY to analyze the trends of tropospheric $\mathrm{NO}_{2}$ over 66 large urban agglomerations worldwide in 2002-2012. Chen et al. [6] compared products from different satellites (GOME, OMI, SCIAMACHY, GOME-2A and GOME-B) across China for 1995-2015. The $\mathrm{NO}_{2}$ products generally had good agreement regarding the spatial pattern. They also found an increasing trend of tropospheric $\mathrm{NO}_{2}$ columns for 1997-2011 but a decreasing trend for 2011-2015. The most important sources of error in retrievals of tropospheric $\mathrm{NO}_{2}$ columns are associated with cloud parameters, surface albedo and $\mathrm{NO}_{2}$ vertical profiles [19]. Irie et al. [20] estimated the biases in the tropospheric $\mathrm{NO}_{2}$ column data from SCIAMACHY, OMI, and GOME-2A in East Asia from 2006-2011. They concluded that the biases are all small (less than about 10\%) and insignificant. They also suggested that these small biases allow for analyses combining these satellite data for air quality studies. Because of the short lifetime of $\mathrm{NO}_{2}$ in the troposphere, $\mathrm{NO}_{2}$ has its largest concentrations close to the emission sources, making satellite measurements of $\mathrm{NO}_{2}$ columns closely correlated to ground-level $\mathrm{NO}_{2}$ concentrations or $\mathrm{NO}_{\mathrm{x}}$ emissions [17, 21]. Han et al. [22] evaluated $\mathrm{NO}_{\mathrm{x}}$ emission fluxes from three inventories (INTEX-B, CAPSS, and REAS) by comparing modeling (CMAQ) results with OMI observations over East Asia in 2006. Many studies [21, 23-26] have also applied satellite observations for model validation. Bechle et al. [27] applied modeled $\mathrm{NO}_{2}$ vertical profiles to covert OMI tropospheric $\mathrm{NO}_{2}$ columns to ground-level $\mathrm{NO}_{2}$ concentrations. They found that using modeled $\mathrm{NO}_{2}$ vertical profiles provided little improvement in ground-level $\mathrm{NO}_{2}$ estimates.

In Thailand, the northern region experiences air pollution haze episodes from forest fires and vegetation fires for land clearing each year during the dry season (January-April). During this period (especially during March-April), air pollutants such as particulate matter with diameter less than 10 micron ( $\left.\mathrm{PM}_{10}\right)$, particulate matter with diameter less than 2.5 micron $\left(\mathrm{PM}_{2.5}\right)$, carbon monoxide $(\mathrm{CO})$, and $\mathrm{NO}_{2}$, have been reported at higher levels compared to other months [26, 28-31]. The mountain ranges surrounding the northern region create a narrow valley which is perfect for trapping air pollutants over the cities causing even higher levels of air pollutants. Moreover, a larger urbanized city such as Chiang Mai is also affected by air pollution because of its increasing traffic congestion [30,32]. Lalitaporn et al. [26] found high concentrations of $\mathrm{NO}_{2}$ in Chiang Mai during biomass burning season of March-April which agreed well with $\mathrm{PM}_{10}$ and CO concentrations. Similarly, Pimpunchat et al. [33] presented high concentrations of $\mathrm{PM}_{10}$ during March-April in Chiang Mai 
owing to haze situation. They also reported high correlation of $\mathrm{PM}_{10}$ concentrations versus $\mathrm{NO}_{2}, \mathrm{CO}$, and $\mathrm{O}_{3}$ concentrations. Wiwatanadate [34] studied the acute effects of open burning-related air pollution in Chiang Mai during January-April of 2008. They found that $\mathrm{NO}_{2}$ was significantly associated with many symptoms including nosebleed, larynx symptoms, dry cough, lower lung symptoms, heart symptoms, and eye irritation. Ground monitoring stations for $\mathrm{NO}_{2}$ and other criteria air pollutants were setup in the northern Thailand by the Pollution Control Department (PCD), Thailand. However, most of them are located in the center of the cities, while they are still sparse in the remote areas where forest fire events generally occur. Therefore, satellite observed data could be useful to assess air pollution information for the areas that lack of ground monitoring stations.

Since $\mathrm{NO}_{2}$ is one of the criteria air pollutants and can be measured globally by satellite sensors, the current study used monthly products of four satellites (SCIMACHY, OMI, GOME-2A, and GOME-2B) to analyze the spatio-temporal variability of tropospheric $\mathrm{NO}_{2}$ columns over northern Thailand for 2003-2016. The comparison between different satellite products was conducted to investigate diurnal variation and its potential use for the long-term study of tropospheric $\mathrm{NO}_{2}$. Ground measurements of $\mathrm{NO}_{2}$ concentrations and satellite-observed fire hotspots were also compared with satellite $\mathrm{NO}_{2}$ data to assess the consistency between them.

\section{Materials and Methods}

\subsection{Ground Monitoring Data}

This study focused on the analysis of $\mathrm{NO}_{2}$ levels in the upper part of northern Thailand. Ground monitoring data was based on hourly $\mathrm{NO}_{2}$ concentrations collected by PCD, Thailand over 10 stations in six cities (Chiang Mai, Lamphun, Lampang, Nan, Phrae, and Phayao) in northern Thailand for 2003-2016. Table 1 and Fig. 1 present the locations of the PCD monitoring stations considered in this study. The PCD reference method used for measuring $\mathrm{NO}_{2}$ concentrations is chemiluminescence.

Table 1. Locations of ground monitoring $\mathrm{NO}_{2}$ stations and satellite grid boxes.

\begin{tabular}{|c|c|c|c|c|c|}
\hline \multicolumn{2}{|c|}{ Satellite grid box } & \multicolumn{4}{|c|}{ Ground monitoring station } \\
\hline ID & $\begin{array}{l}0.5 \times 0.5^{\circ} \text { box } \\
\text { (latitude, longitude) }\end{array}$ & ID & Station name & City & Available year \\
\hline \multirow{3}{*}{1} & \multirow{3}{*}{$\begin{array}{l}18.50-19.00^{\circ} \mathrm{N} \\
98.75-99.25^{\circ} \mathrm{E}\end{array}$} & 1 & Chiang Mai City Hall & Chiang Mai & 1996-present \\
\hline & & 2 & Yupparaj Wittayalai School & Chiang Mai & 1996-present \\
\hline & & 3 & Provincial Administrative Stadium & Lamphun & 2009-present \\
\hline \multirow{4}{*}{2} & \multirow{4}{*}{$\begin{array}{l}18.00-18.50^{\circ} \mathrm{N}, \\
99.50-100.00^{\circ} \mathrm{E}\end{array}$} & 4 & City Pillar Shrine & Lampang & 1996-present \\
\hline & & 5 & \multirow{3}{*}{$\begin{array}{l}\text { Health Promotion Hospital Sob Pad } \\
\text { Health Promotion Hospital Ta See } \\
\text { Provincial Waterworks Authority Mae } \\
\text { Moh }\end{array}$} & Lampang & 1996-present \\
\hline & & 6 & & Lampang & 1996-present \\
\hline & & 7 & & Lampang & 1996-present \\
\hline 3 & $\begin{array}{l}18.50-19.00^{\circ} \mathrm{N} \\
100.50-101.00^{\circ} \mathrm{E}\end{array}$ & 8 & Municipality Office & Nan & 2009-present \\
\hline 4 & $\begin{array}{l}18.00-18.50^{\circ} \mathrm{N} \\
100.00-100.50^{\circ} \mathrm{E}\end{array}$ & 9 & Meteorological Station & Phrae & 2010-present \\
\hline 5 & $\begin{array}{l}19.00-19.50^{\circ} \mathrm{N}, \\
99.75-100.25^{\circ} \mathrm{E}\end{array}$ & 10 & Knowledge Park & Phayao & 2010-present \\
\hline
\end{tabular}



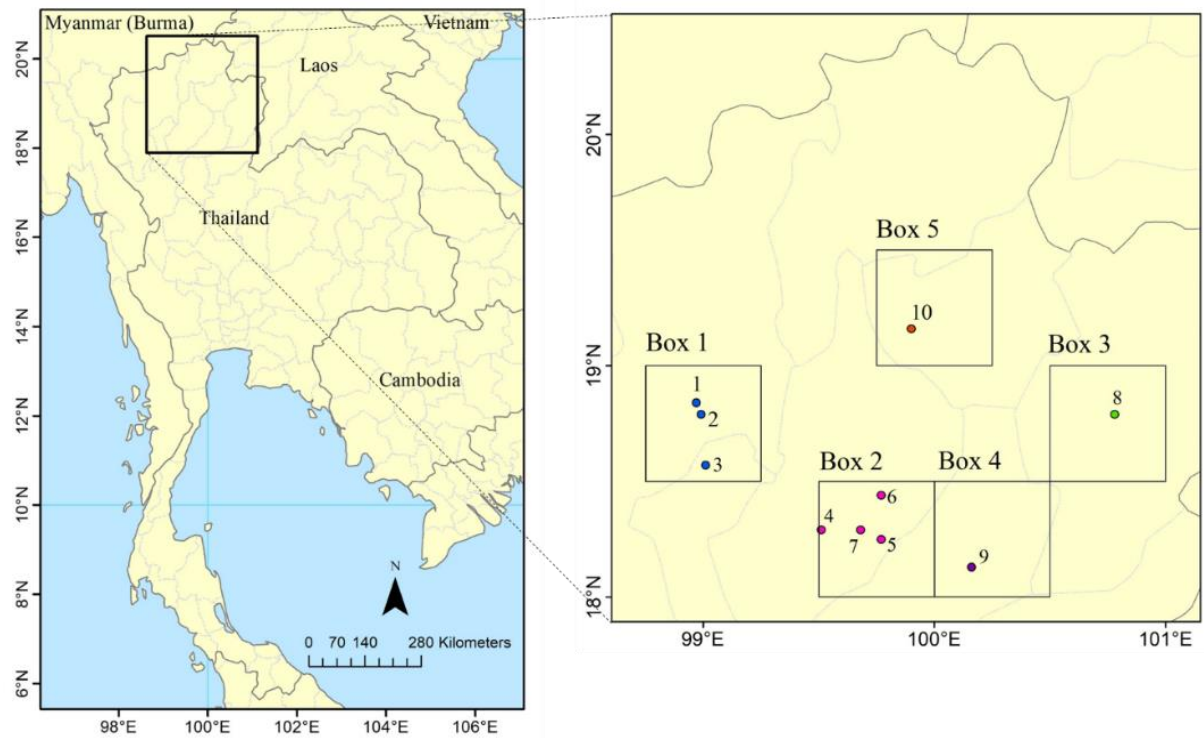

Fig. 1. Locations of 10 PCD stations and 5 satellite grid boxes.

\subsection{Satellite Observation Data}

The satellite $\mathrm{NO}_{2}$ data were retrieved as monthly mean tropospheric $\mathrm{NO}_{2}$ columns (unit: molecule per $\mathrm{cm}^{2}$ ) from level-2 products of SCIAMACHY, OMI, GOME-2A, and GOME-2B for 2003-2016. OMI [35-36] and GOME-2A/B $[19,37]$ provide nearly global coverage in one day with a spatial resolution of $13 \times 24 \mathrm{~km}^{2}$ and $80 \times 40 \mathrm{~km}^{2}$, respectively. For SCIAMACHY [19,38], global coverage requires 6 days with a spatial resolution of $60 \times 30 \mathrm{~km}^{2}$. The original satellite retrievals are regridded on a regular $0.125^{\circ} \times 0.125^{\circ}$ grid for OMI and on a regular $0.25^{\circ} \times 0.25^{\circ}$ grid for SCIAMACHY, GOME- $2 \mathrm{~A}$, and GOME-2B by averaging the satellite observations weighted by the size of the overlapping surface area [18]. SCIAMACHY, GOME-2A, and GOME-2B have a satellite overpass local time (LT) in the morning of approximately 9:30 LT for SCIAMACHY and 10:30 LT for GOME-2A/B. While, OMI overpasses in the afternoon of approximately 13:45 LT. Table 2 summarizes the characteristics of the satellite products used in this study. All satellite $\mathrm{NO}_{2}$ data were downloaded as monthly products from the website of the Tropospheric Emission Monitoring Internet Service (TEMIS) of the European Space Agency (ESA) (http://www.temis.nl/index.php).

Data for tropospheric $\mathrm{NO}_{2}$ columns in this study were collected for the following periods:

- SCAIAMACHY: 01/2003-03/2012

- OMI: 10/2004-12/2016

- GOME-2A: 01/2007-12/2012

- GOME-2B: 01/2013-12/2016

Two-year data of fire hotspots retrieved from the Moderate Resolution Imaging Spectroradiometer (MODIS) onboard the Terra (10:30 LT) and Aqua (13:30 LT) platforms were collected for analysis in this study for 2015-2016. The MODIS fire products of Terra and Aqua detect fires in 1-km pixels that are burning at the time of satellite overpasses. The data are available at the website of Geo-Informatics and Space Technology Development Agency (GISTDA) (http://fire.gistda.or.th/). More details of MODIS fire products are available in Justice et al. [39].

Table 2. Characteristics of satellite $\mathrm{NO}_{2}$ products.

\begin{tabular}{lccr}
\hline Satellite sensor & SCIAMACHY & OMI & GOME-2 \\
\hline Platform & Envisat & Aura & MetOp-A/B \\
Spectral range $(\mu \mathrm{m})$ & $0.23-2.38$ & $0.27-0.50$ & $0.24-0.79$ \\
Ground resolution $\left(\mathrm{km}^{2}\right)$ & $60 \times 30$ & $13 \times 24$ & $80 \times 40$ \\
Overpass local time & $10: 00$ & $13: 45$ & $09: 30$ \\
Operating time & Mar 2002-Apr 2012 & Jul 2004-present & Oct 2006-present/ \\
& & & Sep 2012-present \\
\hline
\end{tabular}




\subsection{Data Analysis}

First, the comparison between four satellite products of tropospheric $\mathrm{NO}_{2}$ columns was conducted based on simple linear regression analysis to investigate the consistency between them. Since the four satellites considered in this study have different ground resolutions (regridded on a $0.125^{\circ} \times 0.125^{\circ}$ grid for $\mathrm{OMI}$ and on a $0.25^{\circ} \times 0.25^{\circ}$ grid for SCIAMACHY, GOME- $2 \mathrm{~A}$, and GOME-2B), five $0.5^{\circ} \times 0.5^{\circ}$ grid boxes were set up around ground monitoring stations of interest. All satellite pixels falling within the decided grid boxes were then extracted using Python version 2.7 for the comparison among satellite products. Table 1 and Fig. 1 present the locations and details of the five grid boxes used in this study. Furthermore, fire hotspots within the considered area were also retrieved from MODIS-Terra and -Aqua and compared with each other.

The comparative analysis between satellite and ground $\mathrm{NO}_{2}$ data was performed based on 3-hour averages of ground $\mathrm{NO}_{2}$ concentrations covering the satellite overpass times. Hourly ground $\mathrm{NO}_{2}$ concentrations were collected for 9:00-12:00 LT and for 12:00-15:00 LT corresponding to the satellite overpass times in the morning (9:30 LT for GOME-2A/B and 10:00 LT for SCIAMACHY) and afternoon (13:45 LT for OMI), respectively. Collected ground data were then averaged as monthly and yearly means for comparison with the satellite data. All ground data falling within the same $0.5^{\circ} \times 0.5^{\circ}$ grid boxes as satellite data were grouped and averaged for comparison with satellite data for concurrent locations and time periods. It is noteworthy that ground measurements of $\mathrm{NO}_{2}$ concentrations represent point-based data at a single location whereas satellite data represent spatial averages of $\mathrm{NO}_{2}$ over a specific land area. In addition, ground $\mathrm{NO}_{2}$ data are time averaged (in this case are 3-hour averaged) whereas satellite $\mathrm{NO}_{2}$ data are measured at a single time when the satellite overpass. Therefore, even if both measurements are error-free, there could be uncertainty in the comparison between ground and satellite datasets owing to the mismatch of spatial and temporal averaging [27, 40]. Finally, spatial distributions of tropospheric $\mathrm{NO}_{2}$ columns from four satellites were also depicted for the northern region of Thailand by using ArcMap version 10.3.1.

During the study period, satellite monthly products of $\mathrm{NO}_{2}$ included more data gaps than monthly data of PCD NO 2 . According to data collection periods, SCIAMACHY, OMI, GOME-2A, and GOME-2B had missing data (calculated from total possible data of all boxes) of 19.82\% (from 555), $0.54 \%$ (from 735), 5.00\% (from 360), and 1.67\% (from 240), respectively. Monthly PCD data averaged for each box in the morning (9:00-12:00) had no missing data, and in the afternoon (12:00-15:00) had missing data of 0.34\% (from 586). Outlier treatment for satellite and ground data was also considered before performed the data analysis. However, satellite and ground data that had high values generally revealed together during haze episodes which implied large emissions from fires. Thus, these data were kept for the analysis.

\section{Results and Discussion}

\subsection{Comparisons among Satellite Products}

Data consistency among the tropospheric $\mathrm{NO}_{2}$ columns from the four satellite products was analyzed. Four pairs of different monthly satellite datasets (OMI versus SCIAMACHY, GOME-2A versus SCIAMACHY, OMI versus GOME-2A, and OMI versus GOME-2B) within overlapping years at the concurrent locations (box ID 1-5) were compared based on simple linear regressions and the results are presented in Fig. 2(a). The results showed a relatively good correlation between the different datasets with the $r$-values in the range $0.82-0.88$ (at the significance level $(p)<0.001$ ). The results were slightly better when the analysis was focused only on the 7 months of the year (October-April) covering the dry period in Thailand, with the r-values improving to $0.85-0.90(p<0.001)$ as presented in Fig. 2(b). The slope of the comparison between tropospheric $\mathrm{NO}_{2}$ columns retrieved from SCIAMACHY and GOME-2A was close to 1.00 (slope = 1.05) showing good agreement between their datasets. This can be explained by their similarities in satellite overpass times and spatial resolutions. Chen et al. [6] also reported similar results across China with slightly higher levels of tropospheric $\mathrm{NO}_{2}$ columns from SCIAMACHY compared to GOME-2A (slope $=1.18$ ). The regression analysis between OMI and other satellite datasets indicated higher levels of tropospheric $\mathrm{NO}_{2}$ columns from OMI than those from SCIAMACHY, GOME-2A, and GOME-2B with slopes in the range $0.69-0.70$. The discrepancy in this case was caused mainly by the differences in satellite overpass times as OMI collects data in the afternoon (13:45 LT) while SCIAMACHY, GOME-2A, and GOME-2B collect data in the morning (9:30-10:30 LT). According to previous studies [41-42], the major source of nitrogen oxide or $\mathrm{NO}_{\mathbf{x}}$ (mainly $\mathrm{NO}_{2}$ and $\mathrm{NO}$ ) emissions in Thailand and Southeast Asia is road transportation. High 
concentrations of $\mathrm{NO}_{2}$ are generally produced during the morning rush hour from transportation, with the concentration reducing in the afternoon due to the higher photolysis rate [21]. However, in this case, OMI recorded higher levels in the tropospheric $\mathrm{NO}_{2}$ columns, implying that there were higher emissions of $\mathrm{NO}_{2}$ from activities in the afternoon in the northern Thailand. Figure 3 displays the number of monthly total fire hotspots retrieved from MODIS-Terra and -Aqua in the northern region for 2015-2016. During JanuaryApril, specifically in March, notably larger numbers of fire hotspots were detected by MODIS-Aqua (13:30 LT) than MODIS-Terra (10:30 LT). A similar study [43] used the MODIS fire hotspots from 2002-2010 for analysis of fire events in the Asian region. They reported that MODIS-Aqua captured $70 \%$ of the fires relative to MODIS-Terra. Arunrat et al. [28] presented times of the day for burning crop residues in Chiang Mai. They found that most of the farmers burned the crop residues (67\% of grain maize and seed maize residues and $86 \%$ of crop residue from the integrated farming system) in the afternoon (12:01-18:00 LT) compared to in the morning (06:01-12:00 LT) and in the evening (18:01-06:00 LT). A previous study [44] also demonstrated that over tropical biomass-burning regions, SCIAMACHY recorded lower tropospheric $\mathrm{NO}_{2}$ columns than OMI (up to 40\%). This suggests that biomass-burning activities in the afternoon can be an important cause of the greater levels of tropospheric $\mathrm{NO}_{2}$ columns observed by OMI in the northern Thailand. However, further analysis on diurnal variation in biomass burning emission in each area of the northern region would provide stronger conclusion. The discrepancy among these satellite products can also be from the biases in satellite retrieved data. However, in accordance with Irie et al. [20], the biases in these datasets (SCIAMACHY, OMI and GOME-2A products) are small and insignificant. Furthermore, from Fig. 2(b), it is noticeable that the highest levels of the tropospheric $\mathrm{NO}_{2}$ columns were recorded in March which were related to the number of fire hotspots. Besides source emission from biomass-burning activities, meteorology also plays a key role in contributing to high $\mathrm{NO}_{2}$ levels during February-April. In particular, stagnant air condition, radiative inversion (associated with calm wind, clear sky and low mixing height) and subsidence inversion (influenced by the northeast monsoon with cold dry air) are prevalent in the northern region during these months [32]. These weather conditions can restrict the dispersion of air pollutants and then subsequently enhance the built-up of high $\mathrm{NO}_{2}$ levels as well.

For the wet period of May to September, the correlation between the four satellites datasets were poor with low r-values of $0.29-0.49$ as presented in Fig. 2(c). In general, the presence of clouds can introduce uncertainties in satellite observations of tropospheric trace gases [19, 45]. Kim Oanh and Leelasakultum [32] showed that it is less cloudy during the dry months in the northern region of Thailand. This perhaps causes better correlation of tropospheric $\mathrm{NO}_{2}$ columns between different satellites datasets in the dry period than in the wet period. In addition, the levels of tropospheric $\mathrm{NO}_{2}$ columns during the wet period were lower than in the dry period which also matched with the seasonal trend of the number of fire hotspots. The monthly mean tropospheric $\mathrm{NO}_{2}$ columns of all considered boxes for each satellite at different periods are illustrated in Fig. 4. Overall, all four satellites recorded higher levels of tropospheric $\mathrm{NO}_{2}$ columns during the dry period with the peak in March. For the morning satellites, the analysis showed that GOME-2B (2013-2016) recorded the highest levels of tropospheric $\mathrm{NO}_{2}$ columns followed by GOME-2A (2007-2012) and SCIAMACHY (2003-2011), respectively. This suggests an increasing trend in $\mathrm{NO}_{2}$ in the northern region. For the afternoon observations, the levels of tropospheric $\mathrm{NO}_{2}$ columns from OMI (2005-2016) were clearly higher than those from the other satellites in March. This highlights the intensive biomass-burning activities in the afternoon during this month. 

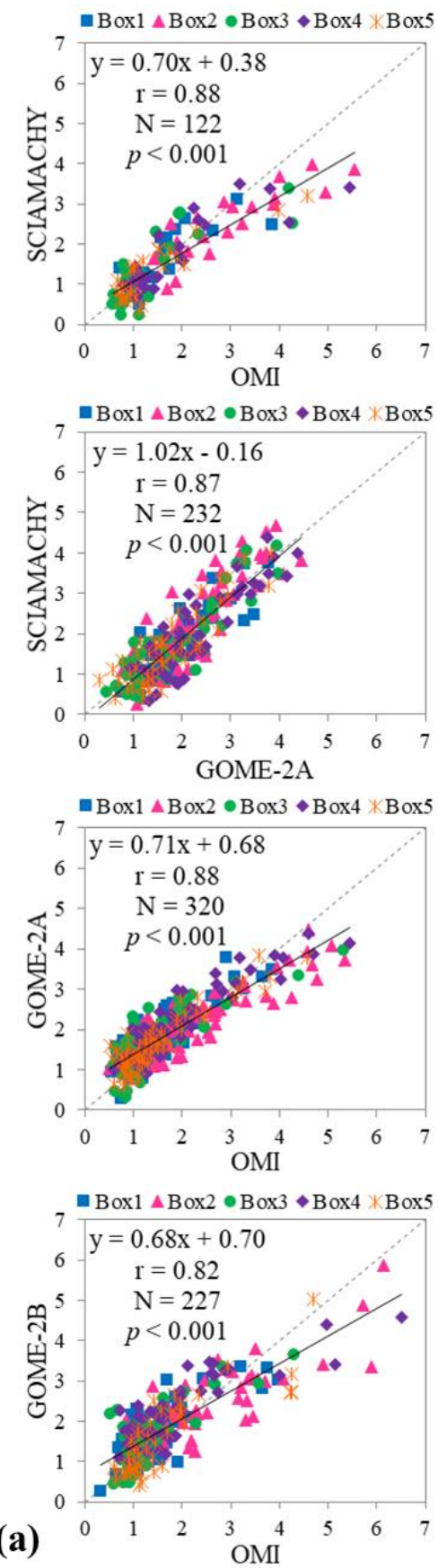
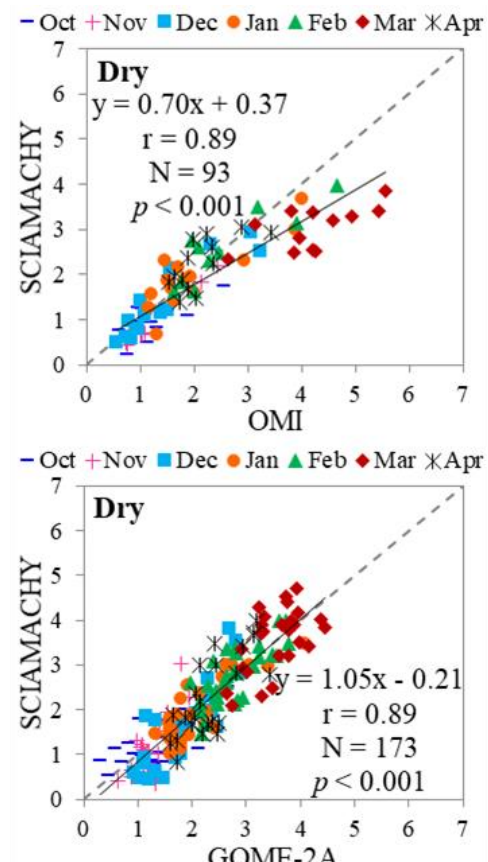

- Oct + Nov $\equiv \mathrm{Dec} \bullet \mathrm{Jan} \triangle \mathrm{Feb} \bullet \mathrm{Mar} * \mathrm{Apr}$

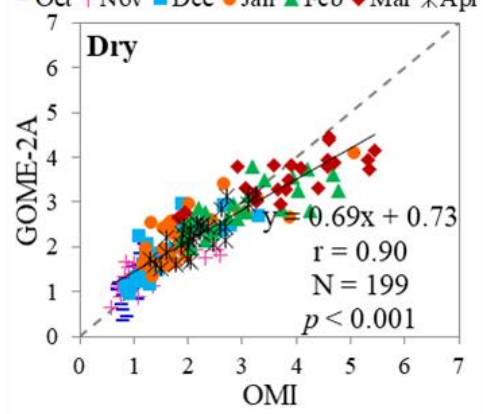

- Oct + Nov $\backsim \mathrm{Dec} \bullet \mathrm{Jan} \Delta \mathrm{Feb} \bullet \mathrm{Mar} * \mathrm{Apr}$

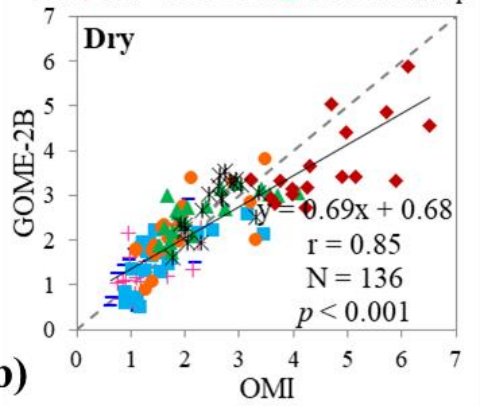

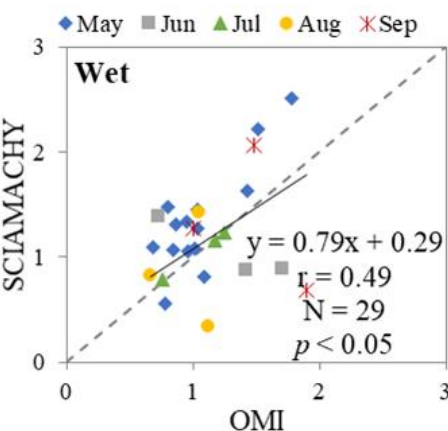
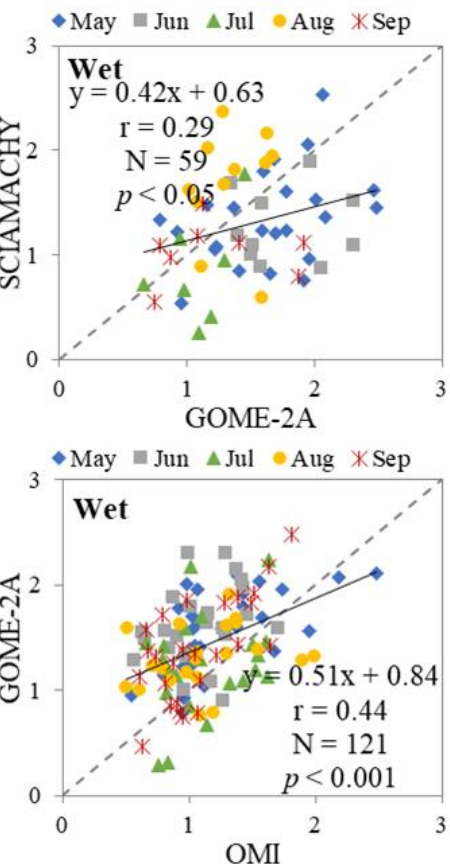

$\bullet$ May $=$ Jun $\Delta$ Jul Aug $*$ Sep

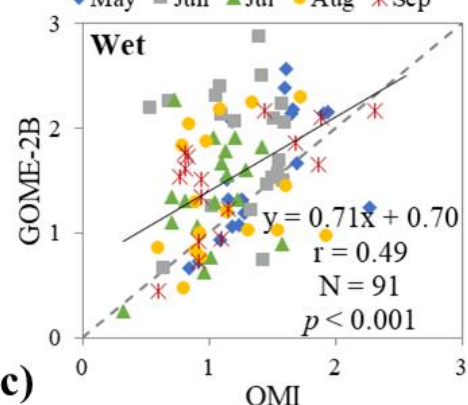

Fig. 2. Scatter plots of tropospheric $\mathrm{NO}_{2}$ columns $\left(10^{15}\right.$ molecule per $\left.\mathrm{cm}^{2}\right)$ extracted from 5 satellite grid boxes (box ID 1-5) of OMI versus SCIAMACHY, GOME-2A versus SCIAMACHY, OMI versus GOME$2 \mathrm{~A}$, and $\mathrm{OMI}$ versus GOME-2B for all months (a), for dry months (b), and for wet months (c). 


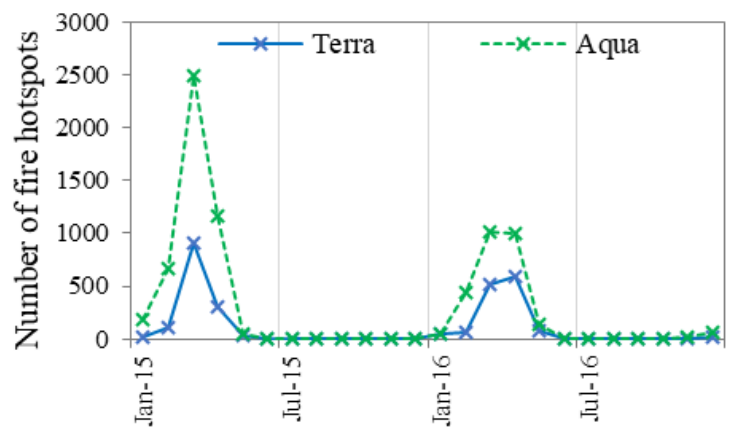

Fig. 3. Monthly total fire hotspots of MODIS-Terra and MODIS-Aqua.

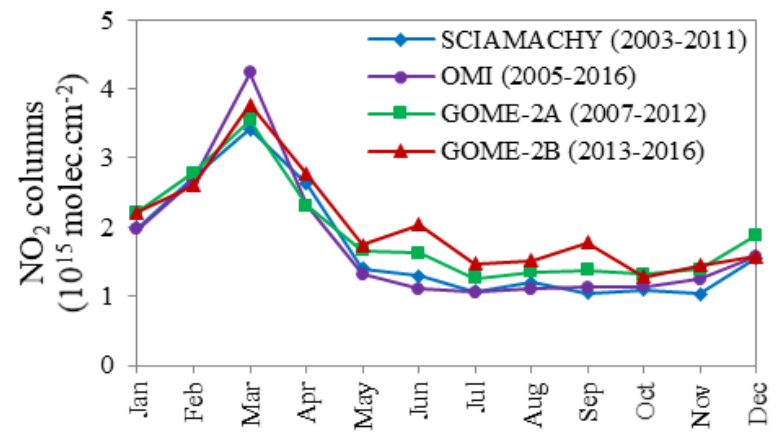

Fig. 4. Monthly mean satellite observations of tropospheric $\mathrm{NO}_{2}$ columns.

\subsection{Monthly Analysis of Satellite and Ground $\mathrm{NO}_{2}$}

Tropospheric $\mathrm{NO}_{2}$ columns were compared with ground $\mathrm{NO}_{2}$ concentrations for the 14-year period 20032016. Figure 5 presents the monthly series of averaged tropospheric $\mathrm{NO}_{2}$ columns retrieved from the three morning satellites (SCIAMACHY, GOME-2A, and GOME-2B) and the averaged ground $\mathrm{NO}_{2}$ concentrations (9:00-12:00 LT). Figure 5(a-e) present the comparisons for boxes with ID 1-5, respectively, and Fig. 5(f) presents the average of all five boxes. Overall, the morning satellite observations were able to capture the seasonal variations of ground $\mathrm{NO}_{2}$ concentrations. The highest levels of $\mathrm{NO}_{2}$ from both satellites and ground monitoring stations were from January-April with the maximum peak in March for all five boxes. Similar results are presented in Fig. 6(a-f) for the monthly series of tropospheric $\mathrm{NO}_{2}$ columns from the afternoon satellite (OMI) plotted with ground $\mathrm{NO}_{2}$ concentrations (12:00-15:00 LT). Table 3 summarizes the results of the correlation analysis between satellite and ground data for all boxes for both the morning and afternoon cases. Overall results showed the r-values in the range $0.43-0.80(p<0.001)$. When the analysis was restricted to only on dry months (October-April), the r-values ranged from $0.54-0.81(p<0.001)$. Most of the r-values in all boxes improved, except for Box 2 for both the morning and afternoon cases. As mentioned in the previous section, one of the main sources of error in determining of tropospheric $\mathrm{NO}_{2}$ columns is cloud parameters and low cloudiness was generally observed during dry months in the northern Thailand. The reason for the better results during the dry months probably due to the less error in the satellite tropospheric $\mathrm{NO}_{2}$ columns in the dry months than in the wet months. Moreover, low mixing height during dry period, especially during February-April [32] can also cause better correlation since when the mixing height is low almost all $\mathrm{NO}_{2}$ are present close to the ground and the satellites will measure almost the same amount of $\mathrm{NO}_{2}$ as measured by ground instruments.

Both satellite and ground $\mathrm{NO}_{2}$ datasets had minimum levels during the wet period. A previous study [46] reported high relative humidity in the northern Thailand during May to October. During these months, more rain and higher wind speed dominated by the southwest monsoon enhance the dilution and dispersion of air pollutants. With the presence of sunlight, water vapor in the atmosphere will produce $\mathrm{OH}$ radicals which subsequently react with $\mathrm{NO}_{2}$ and cause a sink of $\mathrm{NO}_{2}$ in terms of $\mathrm{HNO}_{3}$ [4]. Furthermore, biomass-burning activities during this period are also commonly at a reduced level. For these reasons, the $\mathrm{NO}_{2}$ levels measured during the wet months were lower than in other months. 


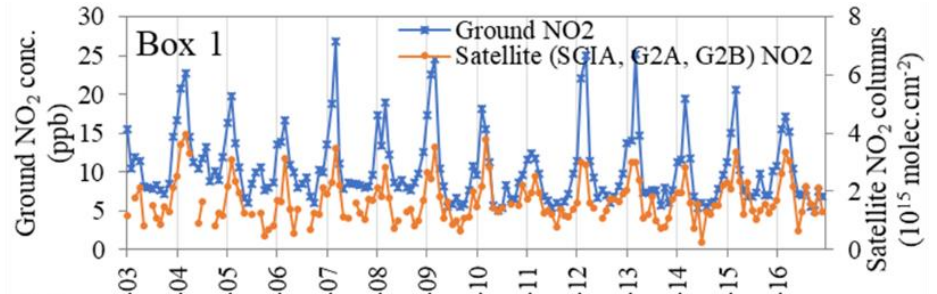

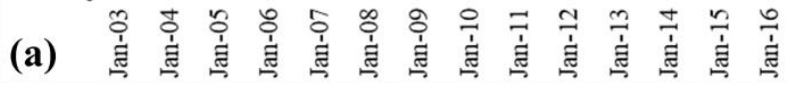

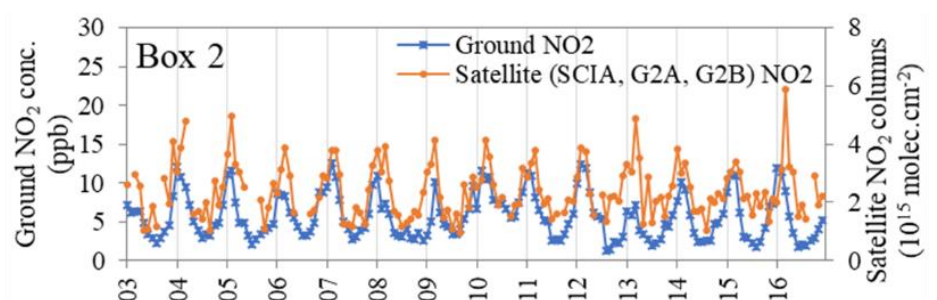

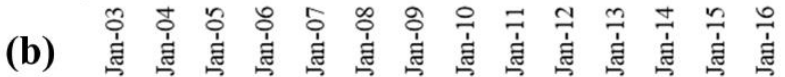

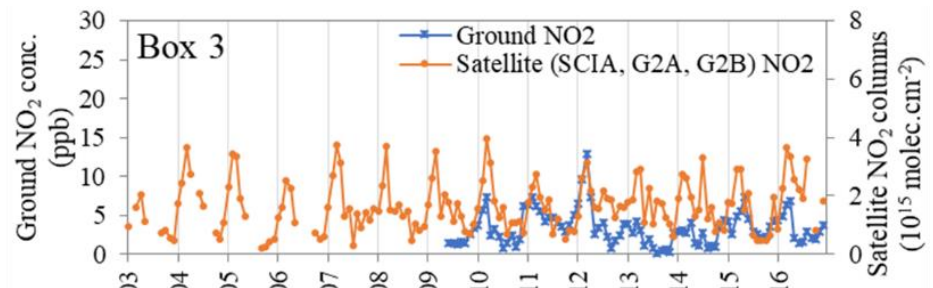

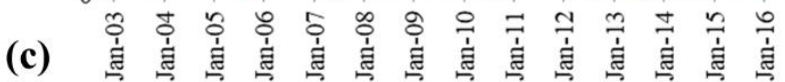

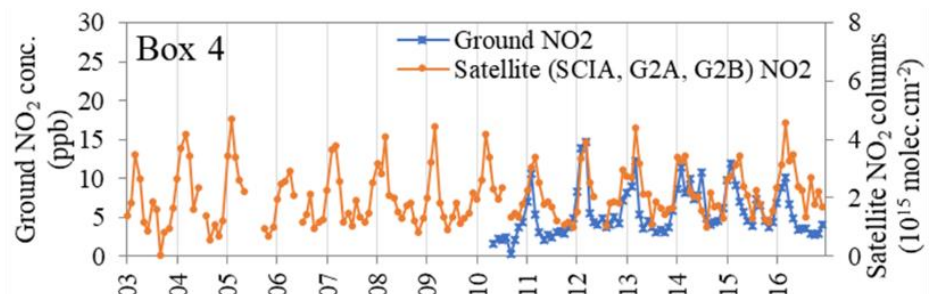

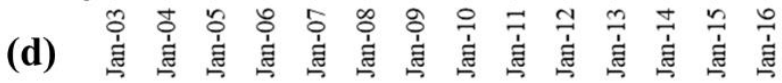

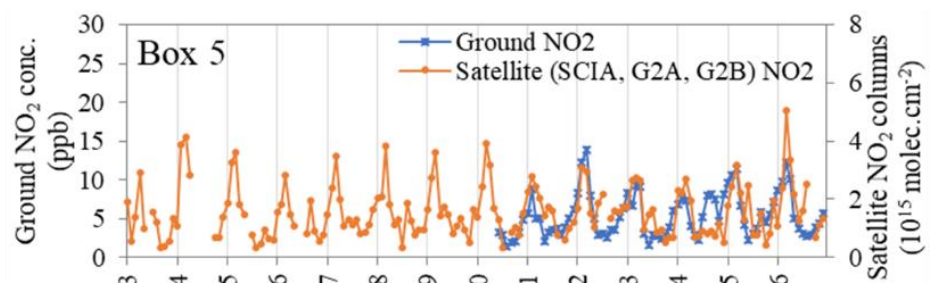

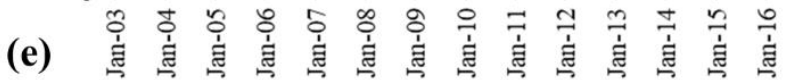

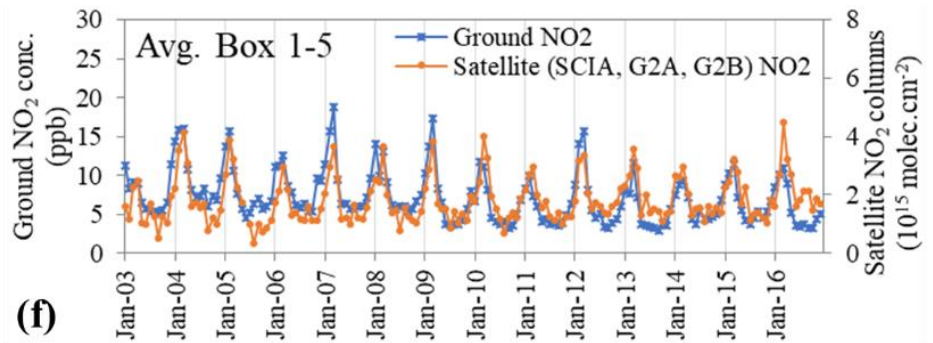

Fig. 5. Time series of morning satellite (SCIAMACHY, GOME-2A, and GOME-2B) $\mathrm{NO}_{2}$ columns and ground $\mathrm{NO}_{2}$ concentrations (9:00-12:00 LT) for box ID 1 (a), box ID 2 (b), box ID 3 (c), box ID 4 (d), box ID 5 (e), and all 5 boxes average (f). 


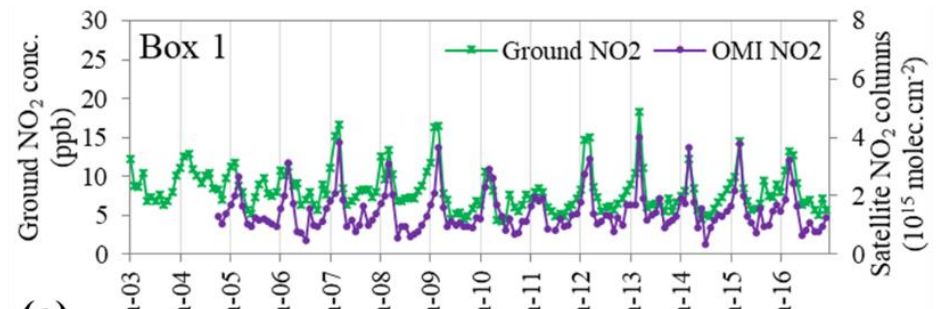

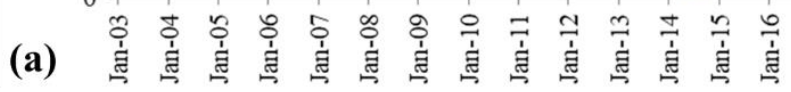

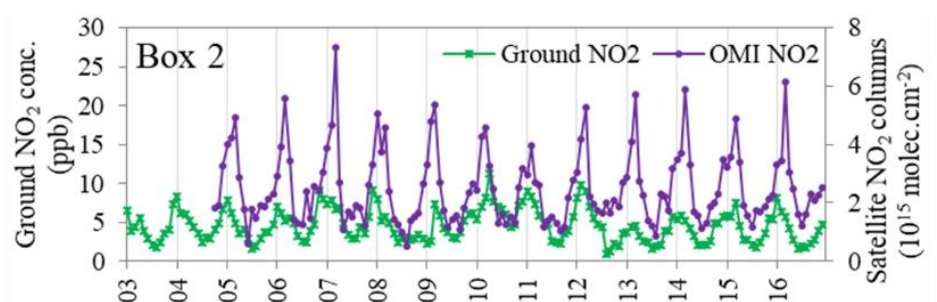

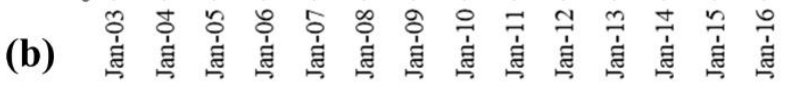

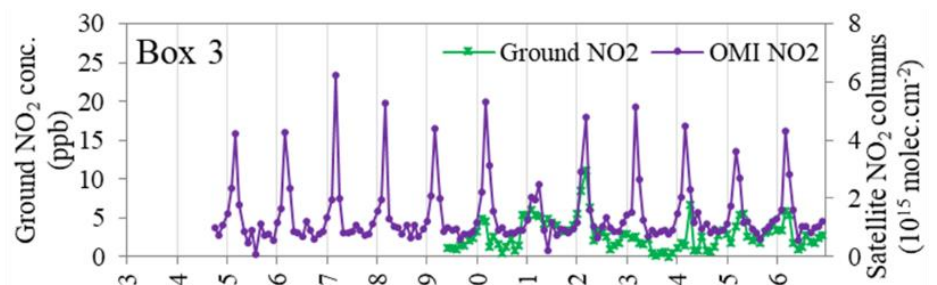

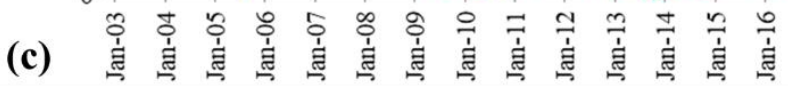

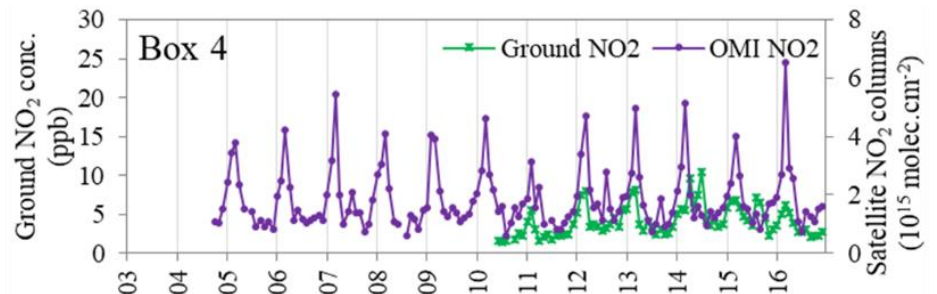

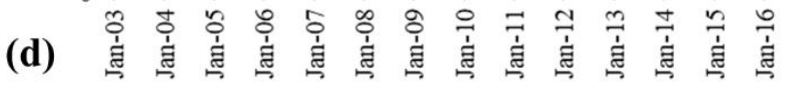

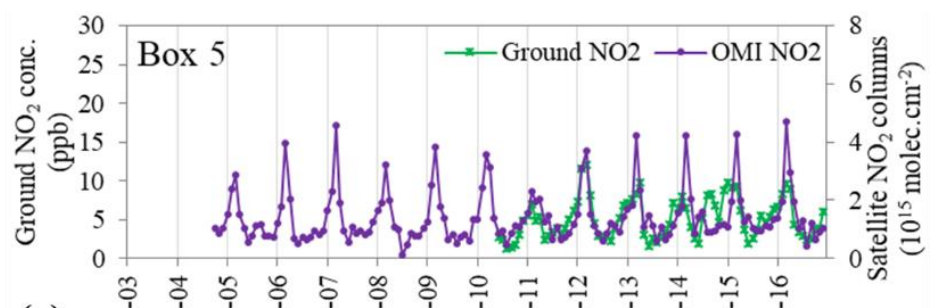

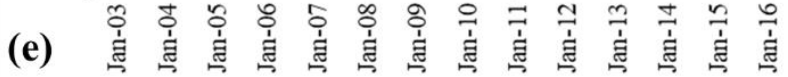

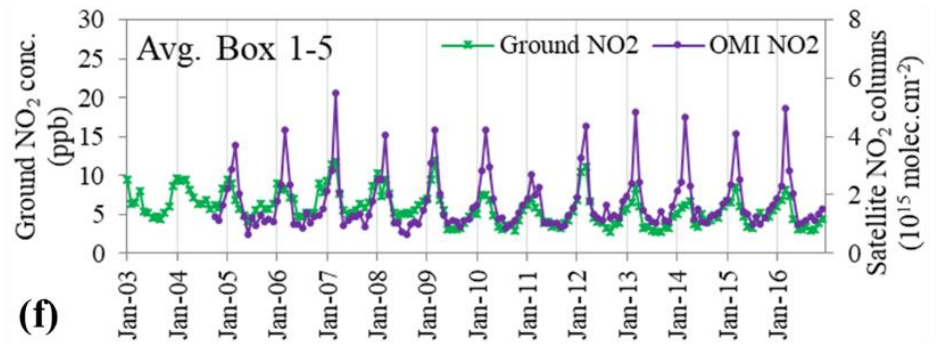

Fig. 6. Time series of afternoon satellite (OMI) $\mathrm{NO}_{2}$ columns and ground $\mathrm{NO}_{2}$ concentrations (12:0015:00 LT) for box ID 1 (a), box ID 2 (b), box ID 3 (c), box ID 4 (d), box ID 5 (e), and all 5 boxes average (f). 
Table 3. Correlation coefficients of satellite and ground $\mathrm{NO}_{2}$ data.

\begin{tabular}{lcccccr}
\hline \multicolumn{7}{c}{ All months } \\
\hline The morning analysis & Box1 & Box2 & Box3 & Box4 & Box5 & Avg. Box1-5 \\
\hline $\mathrm{r}$ & 0.79 & 0.69 & 0.43 & 0.64 & 0.61 & 0.73 \\
$\mathrm{~N}$ & 155 & 156 & 88 & 76 & 75 & 172 \\
$\mathrm{p}$ & $<0.001$ & $<0.001$ & $<0.001$ & $<0.001$ & $<0.001$ & $<0.001$ \\
\hline The afternoon analysis & Box1 & Box2 & Box3 & Box4 & Box5 & Avg. Box1-5 \\
\hline $\mathrm{r}$ & 0.80 & 0.67 & 0.64 & 0.60 & 0.65 & 0.74 \\
$\mathrm{~N}$ & 146 & 147 & 91 & 77 & 79 & 147 \\
$\mathrm{p}$ & $<0.001$ & $<0.001$ & $<0.001$ & $<0.001$ & $<0.001$ & $<0.001$ \\
\hline & \multicolumn{7}{c}{ Dry months } & & \\
\hline The morning analysis & Box1 & Box2 & Box3 & Box4 & Box5 & Avg. Box1-5 \\
\hline $\mathrm{r}$ & 0.79 & 0.56 & 0.54 & 0.73 & 0.72 & 0.74 \\
\hline $\mathrm{N}$ & 96 & 96 & 51 & 45 & 45 & 98 \\
\hline$p$ & $<0.001$ & $<0.001$ & $<0.001$ & $<0.001$ & $<0.001$ & $<0.001$ \\
\hline The afternoon analysis & Box1 & Box2 & Box3 & Box4 & Box5 & Avg. Box1-5 \\
\hline $\mathrm{r}$ & 0.81 & 0.58 & 0.72 & 0.71 & 0.70 & 0.75 \\
\hline $\mathrm{N}$ & 87 & 80 & 51 & 43 & 45 & 87 \\
\hline$p$ & $<0.001$ & $<0.001$ & $<0.001$ & $<0.001$ & $<0.001$ & $<0.001$ \\
\hline
\end{tabular}

Ground $\mathrm{NO}_{2}$ data in the morning (9:00-12:00 LT) and in the afternoon (12:00-15:00 LT) were compared together to investigate diurnal variation between these two periods. Figure 7 shows the monthly mean ground $\mathrm{NO}_{2}$ concentrations averaged from the five boxes considered using the data for 2010-2016. For MayDecember, the levels of $\mathrm{NO}_{2}$ concentrations in the morning and in the afternoon were not much different. However, for January-April, the levels of $\mathrm{NO}_{2}$ concentrations in the afternoon were much higher than in the morning which matched with the results of satellite observations and fire hotspots in the previous section.

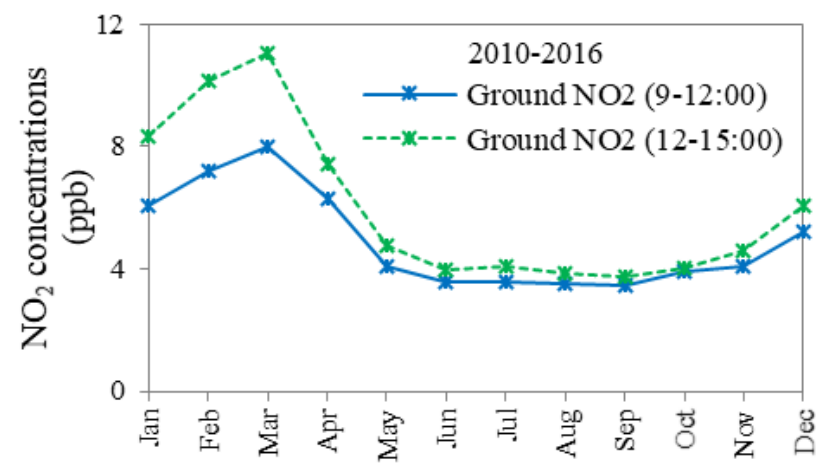

Fig. 7. Monthly mean ground $\mathrm{NO}_{2}$ concentrations in the morning and in the afternoon.

\subsection{Yearly Analysis of Satellite and Ground $\mathrm{NO}_{2}$}

Six-hourly (9:00-15:00) ground $\mathrm{NO}_{2}$ concentrations covering morning and afternoon periods from all 10 stations were yearly averaged for 2010-2016 (ground monitoring $\mathrm{NO}_{2}$ data of station ID 9 and 10 are available from 2010). The averaged ground $\mathrm{NO}_{2}$ data were then compared with tropospheric $\mathrm{NO}_{2}$ columns averaged from four satellites (SCIAMACHY, OMI, GOME-2A, and GOME-2B) from all five boxes. Figure 8 (a) presents the inter-annual variations (solid lines) and linear trends (dot lines) of the satellite and ground $\mathrm{NO}_{2}$ datasets. During this 6-year period, both satellite and ground $\mathrm{NO}_{2}$ had slightly increasing trends of $8.40 \%$ and $1.18 \%$ per 6 years, respectively. For 2010-2013, the inter-annual variation of tropospheric $\mathrm{NO}_{2}$ columns and ground $\mathrm{NO}_{2}$ concentrations correlated well. However, the annual level of tropospheric $\mathrm{NO}_{2}$ columns slightly decreased for 2013-2015 and then increased after 2015, while the annual level of ground $\mathrm{NO}_{2}$ 
concentrations showed the opposite direction after 2013. Figure 8 (b) presents the comparison considered only during dry months (October-April). The inter-annual variation of satellite and ground $\mathrm{NO}_{2}$ were similar to the first case when the analysis was considered all months of the year. However, the results of the dry months presented higher levels of both satellite and ground $\mathrm{NO}_{2}$ data than the results in the first case. The 6 -year trends of satellite and ground $\mathrm{NO}_{2}$ considered during dry months were $7.23 \%$ and $0.48 \%$ per 6 years, respectively.

Spatial distributions of annual mean tropospheric $\mathrm{NO}_{2}$ columns from the morning satellites of SCIAMACHY in 2003, GOME-2A in 2008, GOME-2A in 2012, and GOME-2B in 2016 are presented in Fig. 9(a). The overall results clearly illustrated the increase in tropospheric $\mathrm{NO}_{2}$ columns in the northern region. The afternoon results of OMI in 2008, 2012, and 2016 in Fig. 9(b) also revealed a similar increasing trend. The highest levels of annual mean tropospheric $\mathrm{NO}_{2}$ columns in both the morning and the afternoon were notable in Lampang (box ID 2) and Phrae (box ID 4) compared to the other cities.
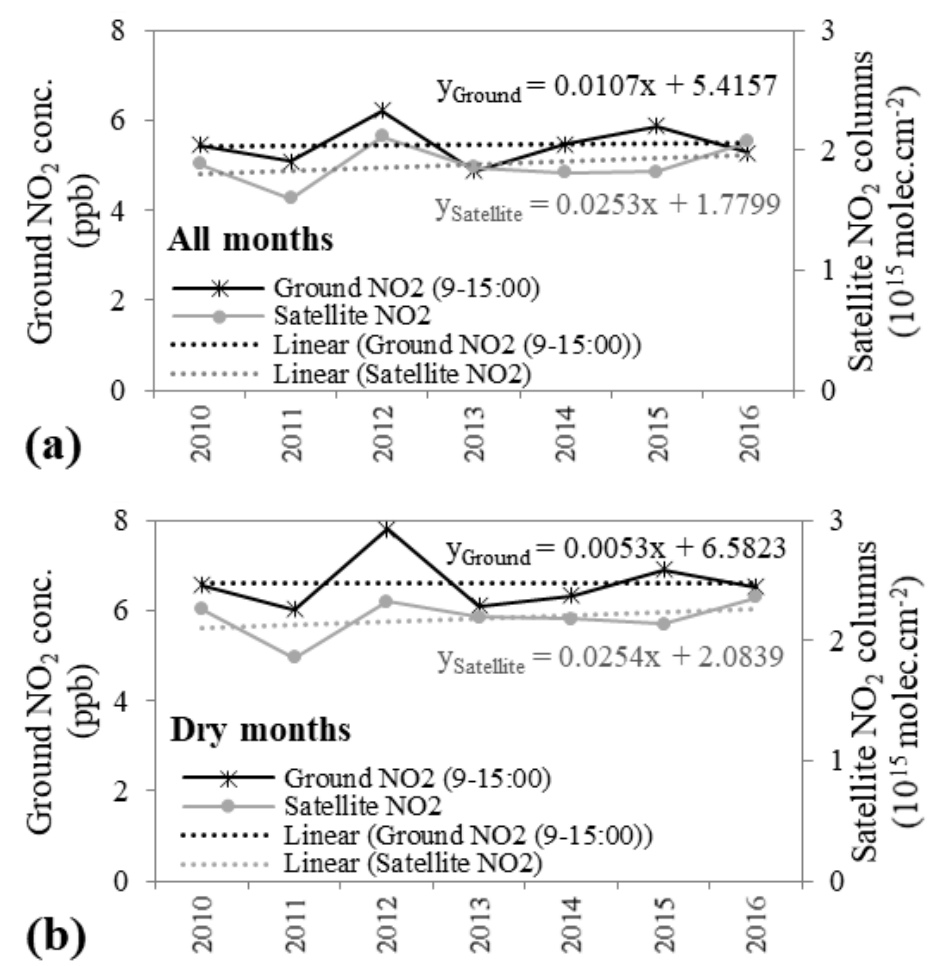

Fig. 8. Annual trends of satellite $\mathrm{NO}_{2}$ columns and ground $\mathrm{NO}_{2}$ concentrations; considered for all months (a) and for dry months (b). 

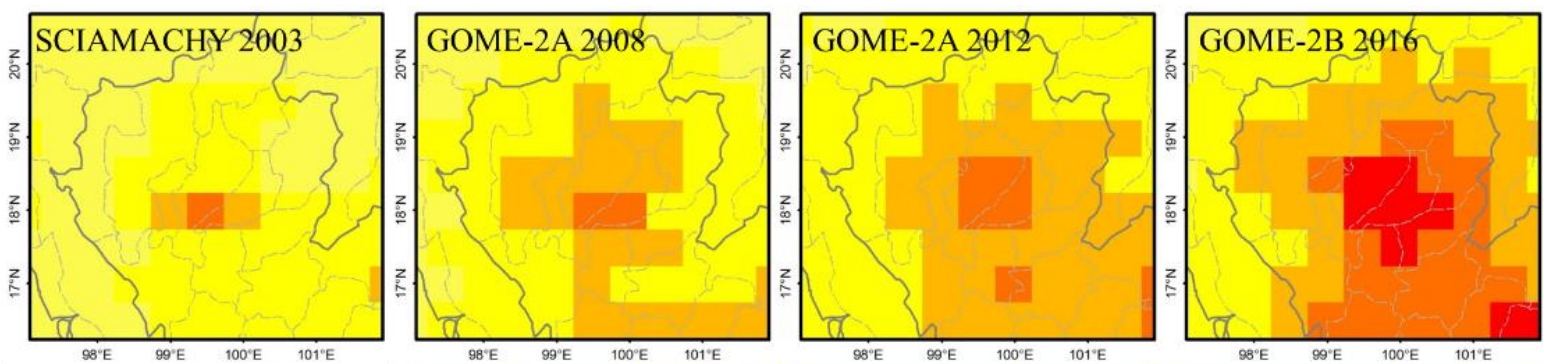

a

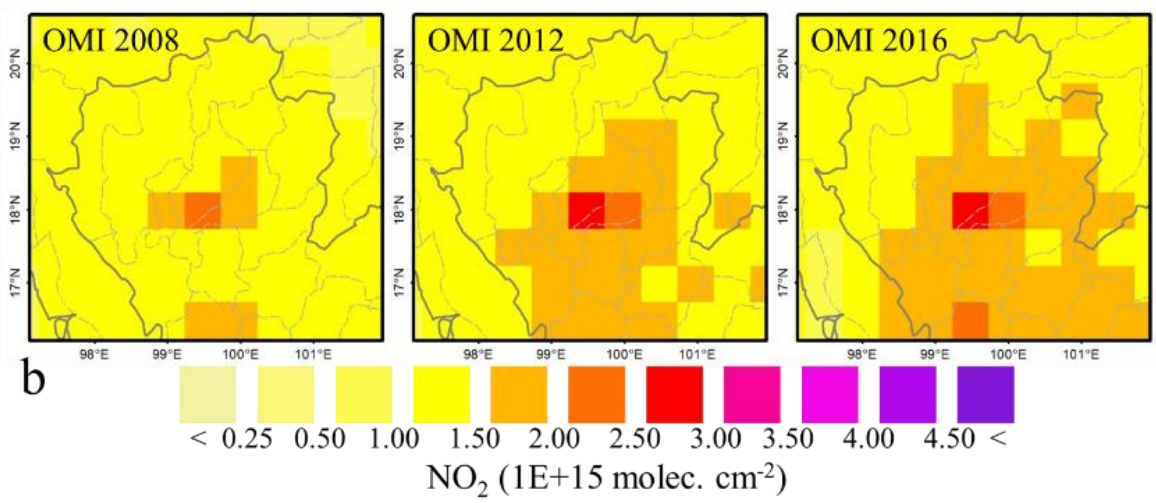

Fig. 9. Spatial distributions of annual mean tropospheric $\mathrm{NO}_{2}$ columns from the morning satellites (a) and the afternoon satellite (b).

Figure 10 shows the comparison of 7-year (2010-2016) averaged data of satellite and ground $\mathrm{NO}_{2}$ levels for each box. The analysis was separated into four cases. For the first and second cases, the $\mathrm{NO}_{2}$ data were obtained from all months of the year (Fig. 10 (a)) and only on dry months (October-April) (Fig. 10 (b)), respectively. The results from both cases showed that the tropospheric $\mathrm{NO}_{2}$ columns averaged from four satellites (SCIAMACHY, OMI, GOME-2A, and GOME-2B) had the highest levels in box ID 2 and the lowest levels in box ID 3. Ground $\mathrm{NO}_{2}$ concentrations averaged for the time 9:00-15:00 LT had the highest levels in box ID 1 and the lowest levels in box ID 3. The $\mathrm{NO}_{2}$ levels from both satellite and ground measurements were not much different between the other boxes. For the third case, the $\mathrm{NO}_{2}$ data were collected for the analysis only on wet months (May-September) (Fig. 10 (c)). The result were similar to the first two cases with the highest levels of tropospheric $\mathrm{NO}_{2}$ columns in box ID 2 and the highest levels of ground $\mathrm{NO}_{2}$ concentrations in box ID 1. It is noteworthy that the satellite data represent the mean $\mathrm{NO}_{2}$ levels covering all the areas of the $0.5^{\circ} \times 0.5^{\circ}$ boxes, whereas the ground data represent the $\mathrm{NO}_{2}$ levels at the points where the ground monitoring stations are located. For box ID 1, the ground monitoring stations were in Chiang Mai and Lamphun cities. Chiang Mai is the most populated city in northern Thailand. Eighty percent of the area is mountains covered with forests. However, the ground monitoring stations are clustered in the urban area where high levels of air pollutants are generally emitted from road traffic, domestic, and industrial sources, which explains the highest levels of $\mathrm{NO}_{2}$ collected from the ground monitoring stations being in box ID 1. On the contrary, the satellites recorded $\mathrm{NO}_{2}$ data from both urban and rural areas and this was probably the cause of the discrepancy between the satellite and ground datasets, since $\mathrm{NO}_{2}$ in rural areas is commonly emitted from biomass-burning activities. Further collection of ground $\mathrm{NO}_{2}$ data in rural areas would clarify this hypothesis. Overall, $\mathrm{NO}_{2}$ levels in the dry months were higher than in the wet months in all boxes. The analysis in the fourth case determined the ratios of $\mathrm{NO}_{2}$ levels in the dry months to in the wet months (Fig. 10 (d)). The results showed that $\mathrm{NO}_{2}$ levels in the dry months were approximately 1.30 2.00 times higher than $\mathrm{NO}_{2}$ levels in the wet months for both satellite and ground measurements. 

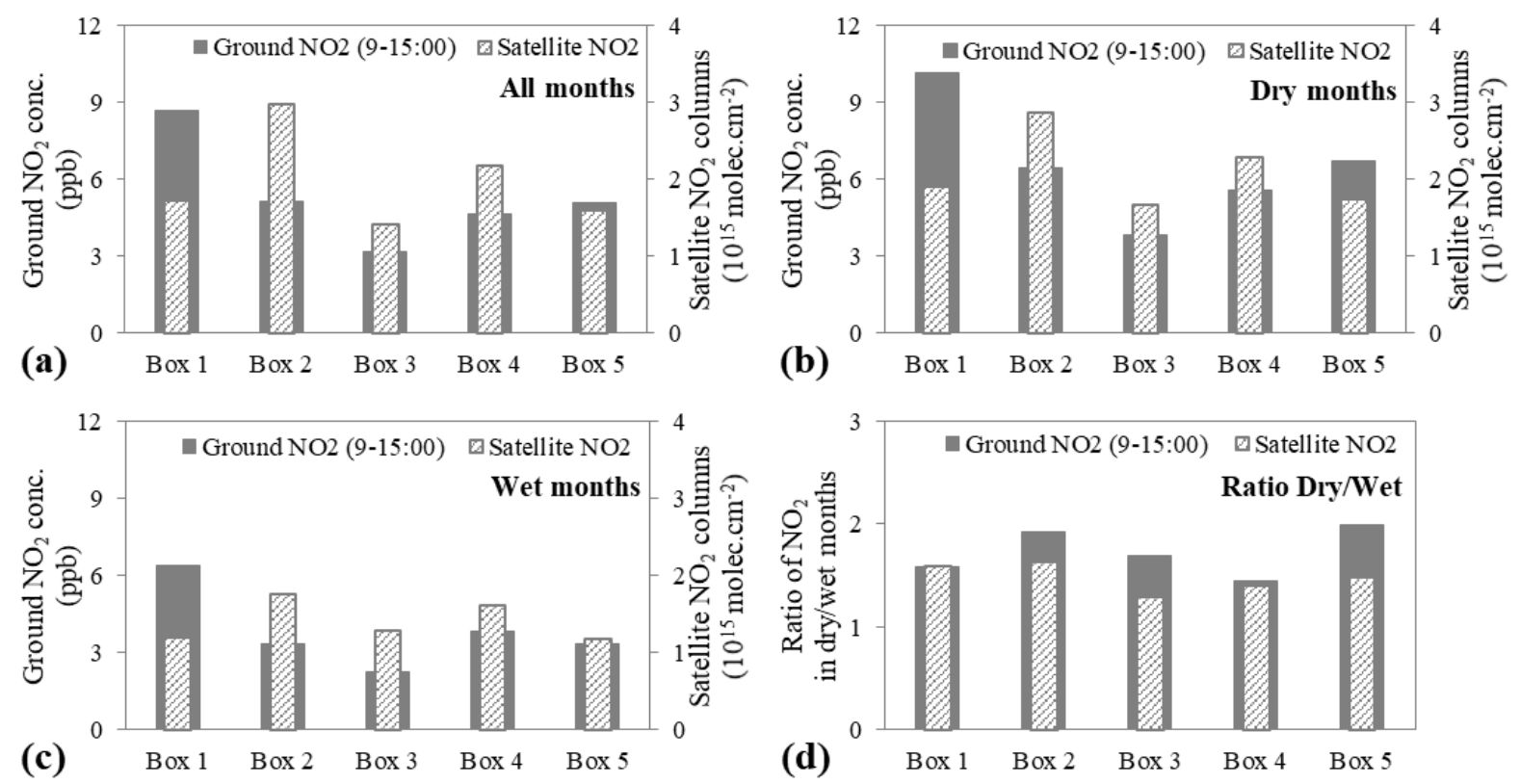

Fig. 10. Comparison of averaged data (2010-2016) of satellite and ground $\mathrm{NO}_{2}$ for the five boxes; considered for all months (a), for dry months (b), for wet months (c), and ratios of $\mathrm{NO}_{2}$ in dry months to in wet months (d).

\section{Conclusions}

Four satellite products of SCIMACHY, OMI, GOME-2A, and GOME-2B were used to analyze temporal and spatial variations of the tropospheric $\mathrm{NO}_{2}$ columns over northern Thailand for 2003-2016. The comparisons among the satellite products showed better correlation during the dry period than the wet period. The afternoon satellite (OMI) generally recorded higher levels of $\mathrm{NO}_{2}$ columns than morning satellites (SCIMACHY, GOME-2A, and GOME-2B), particularly during the biomass-burning period. The results correlated with the number of fire hotspots, highlighting intensive biomass-burning activities in the afternoon. Compared with ground monitoring data, all four satellites were able to detect the seasonal variations in the ground $\mathrm{NO}_{2}$ concentrations. Both satellite and ground measurements recorded maximum levels of $\mathrm{NO}_{2}$ during the peak biomass-burning period of January-April and minimum levels during the wet period of JuneSeptember. When the analysis was restricted to on dry months, the r-values between the satellite and ground datasets were found in the range $0.54-0.81$. Moreover, there were slightly increasing trends in both the satellite and ground $\mathrm{NO}_{2}$ datasets during dry months with values of $7.23 \%$ and $0.48 \%$ per 6 years, respectively, for 2010-2016. Satellite observations indicated that the maximum levels of $\mathrm{NO}_{2}$ were in Lampang, while the ground measurements indicated this occurred in Chiang Mai and Lamphun. This discrepancy was perhaps due to the limited spatial coverage of ground monitoring data. Further collection data of ground $\mathrm{NO}_{2}$ at rural or remote sites will provide more reliable results. However, both satellite and ground measurements showed approximately 1.30-2.00 times higher in $\mathrm{NO}_{2}$ levels in the dry months than in the wet months. In conclusion, this study demonstrated that satellite observations were capable of providing valuable information to supplement existing ground-based data, especially in rural or remote areas where there is still a lack of a ground-based monitoring network. Satellite data can be used to assess spatial and temporal variations of $\mathrm{NO}_{2}$. Integrating satellite measurements with ground-based data would provide a big picture view of $\mathrm{NO}_{2}$ in the atmosphere which is an essential tool for air quality managers to understand the spatial distribution of air pollution for setting air quality policy and mitigation plan in Thailand. Further studies should extend the study areas to other regions of Thailand. Moreover, in order to determine ground-level of $\mathrm{NO}_{2}$ concentrations from satellite columns, further analysis of daily data of satellite and ground $\mathrm{NO}_{2}$ measurements with $\mathrm{NO}_{2}$ vertical profiles will provide a better understanding of the relationship of satellite $\mathrm{NO}_{2}$ columns and ground $\mathrm{NO}_{2}$ concentrations. 


\section{Acknowledgements}

This research was supported by the Kasetsart University Research and Development Institute (KURDI), Bangkok, Thailand. The tropospheric $\mathrm{NO}_{2}$ data of SCIAMACHY, OMI, and GOME-2 were downloaded through the website of the TEMIS project (http://www.temis.nl). MODIS fire hotspots were collected from the GISTDA website (http:// fire.gistda.or.th). Ground $\mathrm{NO}_{2}$ concentrations were provided by the Pollution Control Department, Thailand.

\section{References}

[1] S. Solomon, R. W. Portmann, R. W. Sanders, J. S. Daniel, W. Madsen, B. Bartram, and E. G. Dutton, "On the role of nitrogen dioxide in the absorption of solar radiation," J. Geophys. Res. Atmos., vol. 104, no. D10, pp. 12047-12058, 1999.

[2] J. H. Seinfeld and S. N. Pandis, "Chemistry of the troposphere," in Atmospheric Chemistry and Physics: From Air Pollution to Climate Change, 2nd ed., New York, John Wiley \& Sons, 2006, ch. 6, sec. 6.2, pp. 209-211.

[3] S. Squizzato, M. Masiol, A. Brunelli, S. Pistollato, E. Tarabotti, G. Rampazzo, and B. Pavoni, "Factors determining the formation of secondary inorganic aerosol: A case study in the Po Valley (Italy)," Atmos. Chem. Phys., vol. 13, pp. 1927-1939, 2013.

[4] T. Stavrakou, J.-F. Müller, K. F. Boersma, R. J. van der A, J. Kurokawa, T. Ohara, and Q. Zhang, "Key chemical $\mathrm{NO}_{\mathrm{x}}$ sink uncertainties and how they influence top-down emissions of nitrogen oxides," Atmos. Chem. Phys., vol. 13, pp. 9057-9082, 2013.

[5] J. Ma, A. Richter, J. P. Burrows, H. Nüß, and J. A. van Aardenne, "Comparison of model-simulated tropospheric $\mathrm{NO}_{2}$ over China with GOME-satellite data," Atmos. Environ., vol. 40, pp. 593-604, 2006.

[6] D. Chen, Y. Feng, and X. Zhang, "Comparison of variability and change rate in tropospheric $\mathrm{NO}_{2}$ column obtained from satellite products across China during 1997-2015," Int. J. Digit. Earth, vol. 10, no. 8, pp. 814-828, 2017.

[7] L. M. David and P. R. Nair, "Diurnal and seasonal variability of surface ozone and $\mathrm{NO}_{\mathrm{x}}$ at a tropical coastal site: Association with mesoscale and synoptic meteorological conditions," J. Geophys. Res., vol. 116, no. D10303, pp. 1-16, 2011.

[8] H. Akiyama and H. Tsuruta, "Nitrous oxide, nitric oxide, and nitrogen dioxide fluxes from soils after manure and urea application," J. Environ. Qual., vol. 32, no. 2, pp. 423-431, 2003.

[9] L. Jaeglé, L. Steinberger, R. V. Martin, and K. Chance, "Global partitioning of $\mathrm{NO}_{\mathrm{x}}$ sources using satellite observations: Relative roles of fossil fuel combustion, biomass burning and soil emissions," Faraday Discuss., vol. 130, pp. 407-423, 2005.

[10] S. Beirle, U. Platt, M. Wenig, T. Wagner, "Weekly cycle of $\mathrm{NO}_{2}$ by GOME measurements: A signature of anthropogenic sources," Atmos. Chem. Phys., vol. 3, no. 6, pp. 2225-2232, 2003.

[11] A. Richter, J. P. Burrows, H. Nüß, C. Granier, and U. Niemeier, "Increase in tropospheric nitrogen dioxide over China observed from space," Nature, vol. 437, pp. 129-132, 2005.

[12] Y. He, I. Uno, Z. Wang, T. Ohara, N. Sugimoto, A. Shimizu, A. Richter, and J. P. Burrows, "Variations of the increasing trend of tropospheric $\mathrm{NO}_{2}$ over central east China during the past decade," Atmos. Environ., vol. 41, pp. 4865-4876, 2007.

[13] R. J. van der A, H. J. Eskes, K. F. Boersma, T. P. C. van Noije, M. Van Roozendael, I. De Smedt, D. H. M. U. Peters, and E. W. Meijer, "Trends, seasonal variability and dominant $\mathrm{NO}_{\mathrm{x}}$ source derived from a ten year record of $\mathrm{NO}_{2}$ measured from space," J. Geophys. Res., vol. 113, no. D04302, pp. 1-12, 2008.

[14] L. N. Lamsal, R. V. Martin, A. van Donkelaar, E. A. Celarier, E. J. Bucsela, K. F. Boersma, R. Dirksen, C. Luo, and Y. Wang, "Indirect validation of tropospheric nitrogen dioxide retrieved from the OMI satellite instrument: Insight into the seasonal variation of nitrogen oxides at northern midlatitudes," $J$. Geophys. Res., vol. 115, no. D05302, pp. 1-15, 2010.

[15] H.-J. Lee, S.-W. Kim, J. Brioude, O. R. Cooper, G. J. Frost, C.-H. Kim, R. J. Park, M. Trainer, and J.H. Woo, "Transport of $\mathrm{NO}_{\mathrm{x}}$ in East Asia identified by satellite and in situ measurements and Lagrangian particle dispersion model simulations," J. Geophys. Res. Atmos., vol. 119, pp. 2574-2596, 2014.

[16] K. F. Boersma, D. J. Jacob, M. Trainic, Y. Rudich, I. DeSmedt, R. Dirksen, and H. J. Eskes, "Validation of urban $\mathrm{NO}_{2}$ concentrations and their diurnal and seasonal variations observed from the SCIAMACHY and OMI sensors using in situ surface measurements in Israeli cities," Atmos. Chem. Phys., vol. 9, pp. 3867-3879, 2009. 
[17] A. Hilboll, A. Richter, and J. P. Burrows, "Long-term changes of tropospheric $\mathrm{NO}_{2}$ over megacities derived from multiple satellite instruments," Atmos. Chem. Phys., vol. 13, pp. 4145-4169, 2013.

[18] P. Schneider, W. A. Lahoz, and R. van der A, "Recent satellite-based trends of tropospheric nitrogen dioxide over large urban agglomerations worldwide," Atmos. Chem. Phys., vol. 15, pp. 1205-1220, 2015.

[19] K. F. Boersma, H. J. Eskes, and E. J. Brinksma, "Error analysis for tropospheric $\mathrm{NO}_{2}$ retrieval from space," J. Geophys. Res. Atmos., vol. 109, pp. D04311, 2004.

[20] H. Irie, K. F. Boersma, Y. Kanaya, H. Takashima, X. Pan, and Z. F. Wang, "Quantitative bias estimates for tropospheric $\mathrm{NO}_{2}$ columns retrieved from SCIAMACHY, OMI, and GOME-2 using a common standard for East Asia," Atmos. Meas. Tech., vol. 5, pp. 2403-2411, 2012.

[21] S. Itahashi, I. Uno, H. Irie, J.-I. Kurokawa, and T. Ohara, "Regional modeling of tropospheric $\mathrm{NO}_{2}$ vertical column density over East Asia during the period 2000-2010: Comparison with multisatellite observations," Atmos. Chem. Phys., vol. 14, pp. 3623-3635, 2014.

[22] K. M. Han, S. Lee, L. S. Chang, and C. H. Song, "A comparison study between CMAQ-simulated and OMI-retrieved $\mathrm{NO}_{2}$ columns over East Asia for evaluation of $\mathrm{NO}_{\mathrm{x}}$ emission fluxes of INTEX-B, CAPSS, and REAS inventories," Atmos. Chem. Phys., vol. 15, pp. 1913-1938, 2015.

[23] I. Uno, Y. He, T. Ohara, K. Yamaji, J.-I. Kurokawa, M. Katayama, Z. Wang, K. Noguchi, S. Hayashida, A. Richter, and J. P. Burrows, "Systematic analysis of interannual and seasonal variations of modelsimulated tropospheric $\mathrm{NO}_{2}$ in Asia and comparison with GOME-satellite data," Atmos. Chem. Phys., vol. 7, pp. 1671-1681, 2007.

[24] K. M. Hana, C. K. Lee, J. Lee, J. Kim, and C. H. Song, "A comparison study between model-predicted and OMI-retrieved tropospheric $\mathrm{NO}_{2}$ columns over the Korean peninsula," Atmos. Environ., vol. 45, pp. 2962-2971, 2011.

[25] H. Irie, K. Yamaji, K. Ikeda, I. Uno, S. Itahashi, T. Ohara5, and J. Kurokawa, "An evaluation of the CMAQ reproducibility of satellite tropospheric $\mathrm{NO}_{2}$ column observations at different local times over East Asia," Atmos. Chem. Phys. Discuss., vol. 13, pp. 14037-14067, 2013.

[26] P. Lalitaporn, G. Kurata, Y. Matsuoka, N. Thongboonchoo, and V. Surapipith, "Long-term analysis of $\mathrm{NO}_{2}, \mathrm{CO}$, and AOD seasonal variability using satellite observations over Asia and intercomparison with emission inventories and model," Air Qual. Atmos. Health., vol. 6, pp. 655-672, 2013.

[27] M. J. Bechle, D. B. Millet, and J. D. Marshall, "Remote sensing of exposure to $\mathrm{NO}_{2}$ : Satellite versus ground-based measurement in a large urban area," Atmos. Environ., vol. 69, pp. 345-353. 2013.

[28] N. Arunrat, N. Pumijumnong, and S. Sereenonchai, "Air-pollutant emissions from agricultural burning in Mae Chaem basin, Chiang Mai province, Thailand," Atmos., vol. 9, no. 4, pp. 145. 2018.

[29] B. Mitmark and W. Jinsart, "A GIS model for $\mathrm{PM}_{10}$ exposure from biomass burning in the north of Thailand," App. Envi. Res., vol. 39, no. 2, pp. 77-87, 2017.

[30] S. Sooktawee, U. Humphries, A. Patpai, R. Kongsong, S. Boonyapitak, and N. Piemyai, "Visualization and interpretation of $\mathrm{PM}_{10}$ monitoring data related to causes of haze episodes in Northern Thailand," App. Envi. Res., vol. 37, no. 2, pp. 33-48. 2015.

[31] M. Sukitpaneenit and N. T. Kim Oanh, "Satellite monitoring for carbon monoxide and particulate matter during forest fire episodes in northern Thailand," Environ. Monit. Assess., vol. 186, no. 4, pp. 2495-2504. 2014.

[32] N. T. Kim Oanh and K. Leelasakultum, "Analysis of meteorology and emission in haze episode prevalence over mountain-bounded region for early warning," Sci. Total Environ., vol. 409, pp. 2261-71, 2011.

[33] B. Pimpunchat, K. Sirimangkhala, and S. Junyapoon, "Modeling haze problems in the North of Thailand using logistic regression," J. Math. Fund. Sci., vol. 46, no. 2, pp. 183-193, 2014.

[34] P. Wiwatanadate, "Acute air pollution-related symptoms among residents in Chiang Mai, Thailand," J. Environ. Health, vol. 76, no. 6, pp. 76-85, 2014.

[35] K. F. Boersma, H. J. Eskes, R. J. Dirksen, R. J. van der A, J. P. Veefkind, P. Stammes, V. Huijnen, Q. L. Kleipool, M. Sneep, J. Claas, J. Leitão, A. Richter, Y. Zhou, and D. Brunner, "An improved tropospheric $\mathrm{NO}_{2}$ column retrieval algorithm for the Ozone Monitoring Instrument," Atmos. Meas. Tech., vol. 4, pp. 1905-1928, 2011.

[36] P. F. Levelt, G. H. J. van den Oord, M. R. Dobber, A. Malkki, H. Visser, J. de Vries, P. Stammes, J. O. V. Lundell, and H. Saari, “The ozone monitoring instrument," IEEE Trans. Geosci. Remote Sens., vol. 44, no. 5, pp. 1093-1101, 2006. 
[37] P. Valks, G. Pinardi, A. Richter, J.-C. Lambert, N. Hao, D. Loyola, M. Van Roozendael, and S. Emmadi, "Operational total and tropospheric $\mathrm{NO}_{2}$ column retrieval for GOME-2," Atmos. Meas. Tech., vol. 4, pp. 1491-1514, 2011.

[38] H. Bovensmann, J. P. Burrows, M. Buchwitz, J. Frerick, S. Noël, V. V. Rozanov, K. V. Chance, and A. P. H. Goede, "SCIAMACHY: Mission objectives and measurement modes," J. Atmos. Sci., vol. 56, no. 2, pp. 127-150, 1999.

[39] C. O. Justice, L. Giglio, S. Korontzi, J. Owens, J. T. Morisette, D. Roy, J. Descloitres, S. Alleaume, F. Petitcolin, and Y. Kaufman, “The MODIS fire products," Remote Sens. Environ., vol. 83, pp. 244-262, 2002.

[40] J. Engel-Cox, A. Huff, T. Kanabkaew, and N. T. Kim Oanh, "Satellite tools for air quality management with focus on particulate matter," in Integrated Air Quality Management: Asian Case Studies, N. T. Kim Oanh Ed. Boca Raton, Florida: CRC Press, 2012, ch. 4, pp. 125-148.

[41] B.-N. Zhang and N. T. Kim Oanh, "Photochemical smog pollution in the Bangkok Metropolitan Region of Thailand in relation to $\mathrm{O}_{3}$ precursor concentrations and meteorological conditions," Atmos. Environ., vol. 36, pp. 4211-4222, 2002.

[42] S. Itahashi, I. Uno, H. Irie, J. -I. Kurokawa, and T. Ohara, "Impacts of biomass burning emissions on tropospheric $\mathrm{NO}_{2}$ vertical column density over continental Southeast Asia," in Land-Atmospheric Research Applications in South and Southeast Asia, K. Vadrevu, T. Ohara, and C. Justice, Ed. Springer Remote Sensing/Photogrammetry, 2018, ch. 4, pp. 67-81.

[43] K. P. Vadrevu and C. O. Justice, "Vegetation fires in the Asian region: Satellite observational needs and priorities," Glob. Environ. Res., vol. 15, pp. 65-76, 2011.

[44] K. F. Boersma, D. J. Jacob, H. J. Eskes, R. W. Pinder, J. Wang, R. J. van der A, "Intercomparison of SCIAMACHY and OMI tropospheric $\mathrm{NO}_{2}$ columns: Observing the diurnal evolution of chemistry and emissions from space," J. Geophys. Res., vol. 113, no. D16S26, pp. 1-14, 2008.

[45] Y. Wang, S. Beirle, J. Lampel, M. Koukouli, I. De Smedt, N. Theys, A. Li, D. Wu, P. Xie, C. Liu, M. Van Roozendael, T. Stavrakou, J. F. Müller, and T. Wagner, "Validation of OMI, GOME-2A and GOME-2B tropospheric $\mathrm{NO}_{2}, \mathrm{SO}_{2}$ and $\mathrm{HCHO}$ products using MAX-DOAS observations from 2011 to 2014 in Wuxi, China: Investigation of the effects of priori profiles and aerosols on the satellite products," Atmos. Chem. Phys., vol. 17, pp. 5007-5033, 2017.

[46] P. Lalitaporn, "Temporal and spatial variability of tropospheric $\mathrm{NO}_{2}$ columns retrieved from OMI satellite data and comparison with ground based information in Thailand," Eng. Appl. Sci. Res., vol. 44, no. 4, pp. 227-234, 2017. 